\title{
DIGITALIZACJA PRODUKTÓW BANKOWYCH JAKO CEL STRATEGICZNY UCZESTNIKÓW POLSKIEGO SEKTORA BANKOWEGO
}

\section{WPROWADZENIE}

Polskie banki rozpoczęły transformację cyfrowa ${ }^{1}$ kilka lat temu i z reguły mają przyjęta jasną strategię digitalizacji, obecna sytuacja rynkowa powoduje jednak, że nawet one stoją w obliczu poważnych zmian. W szczególności biorąc pod uwagę, że coraz więcej klientów wykorzystuje telefony komórkowe i tablety do realizacji usług bankowych, a omnikanałowość ${ }^{2}$ zyskuje na znaczeniu, wydaje się, że mobilność rozwiązań staje się kluczowym elementem strategii cyfrowej, której banki muszą sprostać. Ponadto aby utrzymać się na tak szybko zmieniającym się rynku, tradycyjne banki muszą dostosować swoje modele operacyjne do rozwoju technologicznego i innowacji w sferze Internetu. Dostosowania te w szczególności będą dotyczyły usprawnień procesów IT, rozwoju nowych produktów i usług, a co najważniejsze zmieniających się oczekiwań, co do czasu wprowadzenia danego rozwiązania na rynek.

Niezwykle ważna jest również zmiana mentalna wśród pracowników sektora bankowego, którzy muszą się zmierzyć z bezsprzecznym aktualnie wymogiem „klientocentryczności”. Oznacza to, że należy zmienić dotychczasowe podejście, polegające na wprowadzaniu zmian tylko w odniesieniu do konkurencji i sytuacji na rynku. Nastała bowiem era, w której klient odgrywa główna rolę, a bank musi wsłuchać się w rytm jego potrzeb. Przyjmując taki wyznacznik kierunku zmian - instytucja będzie mogła liczyć na sukces. W przeciwnym razie może wiele stracić na rzecz konkurencji. Szczególne wyzwanie stoi tu przed dużymi organizacjami, w których zmiana nawyków i przekonań organi-

${ }^{1}$ Autor definiuje transformację cyfrową jako działania polegające na zmianie modelu biznesowego banku poprzez dostosowanie aktualnych, a także powołanie nowych procesów, narzędzi i rozwiązań (zarówno w ramach oferowanych produktów i usług bankowych - transformacja zewnętrzna, ale i ich obsługi oraz rozwoju kanałów dystrybucji - transformacja wewnętrzna), opartych na nowoczesnych technologiach, w celu sprostania ewoluującym potrzebom klientów.

${ }^{2}$ Omnikanałowość oznacza możliwość zmiany kanału dystrybucji w ramach jednego procesu zakupowego, np. klient realizuje pierwszą część kupna kredytu przez Internet (złożenie wniosku), a następnie może kontynuować realizację w innym kanale - bankowości mobilnej, telefonicznej lub w oddziale. Omnikanałowość różni się od multikanałowości tym, że ta druga daje możliwość wykonania usługi w wielu kanałach, przy czym realizacja następuje od początku do końca w tym samym kanale. 
zacyjnych może stanowić dużą barierę, na czym z pewnością skorzystają mali gracze w procesie digitalizacji, którzy będą zwiększać swój udział w rynku ze znacznie wyższą dynamika.

O tym, jak istotny jest aspekt transformacji cyfrowej, nie tylko w Polsce i nie tylko w sektorze bankowym, świadcza prognozy International Data Corporation, która szacuje, że ${ }^{2}{ }_{3}$ największych światowych spółek do końca 2017 r. ustanowi digitalizacje jako centralny element swojej strategii biznesowej. Ponadto IDC przewiduje, że odsetek usług doradczych związanych z digitalizacja wzrośnie z 50\% w latach 2013-2015 do 80\% w 2019 r. pośród wszystkich usług konsultingowych z zakresu biznesu i technologii informacyjnych, a wartość całego rynku usług dotyczacych strategii cyfrowej w 2019 r. wyniesie $97 \mathrm{mld}$ USD [IDC 2015]. Statystyki przeprowadzone przez IDC pokazują nieodwracalny trend w kierunku zaspokojenia potrzeb społeczeństwa cyfrowego.

Problemem badawczym niniejszego artykułu jest cyfryzacja działalności banków w Polsce. Celem głównym artykułu jest włączenie się w nurt dyskusji na temat digitalizacji polskiego sektora bankowego oraz wskazanie wyzwań, przed jakim stoją jego uczestnicy w obliczu zmieniajacych się potrzeb klientów. Autor stawia hipotezę, że brak reakcji na ewolucję oczekiwań odbiorców usług spowoduje stopniową utratę klientów, a co za tym idzie - spadek przychodów banku. Do rozwiązania problemu badawczego autor posłużył się metodą historyczna, dokonując przeglądu i porządkowania literatury polsko- i anglojęzycznej, oraz metodą dedukcyjna, polegającą na wnioskowaniu dedukcyjnym opartym na wynikach badań przeprowadzonych przez wybrane firmy konsultingowe.

\section{GENEZA CYFRYZACJI W UJĘCIU STRATEGICZNYM}

Za pierwsza z przyczyn włączenia transformacji cyfrowej do nurtu działań strategicznych w sektorze bankowym uznać można ewolucję orientacji marketingowych przedsiębiorstw, spowodowana poszukiwaniem skutecznych sposobów na efektywne działanie podmiotów gospodarczych w danej sytuacji rynkowej. Na przestrzeni lat analizowano zachowania przedsiębiorstw ${ }^{3}$ i na tej podstawie określono różne rodzaje ich orientacji biznesowej. Należą do nich następujace orientacje:

- produkcyjna,

- sprzedażowa,

- marketingowa,

- strategiczna,

- społeczna ${ }^{4}$.

${ }^{3}$ Jednym z pierwszorzędnych naukowców zajmujących się tą problematyką jest Philip Kotler.

${ }^{4}$ M. Sławińska, Istota i znaczenie marketingu w zarzqdzaniu przedsiębiorstwem, w: H. Mruk, B. Pilarczyk, M. Sławińska, Marketing. Koncepcje - strategie - trendy, Wyd. UEP, Poznań 2015, s. 19, za: P. Kotler et al., Marketing. Podręcznik europejski, PWE, Warszawa 2002, s. $49-54$. 
Pierwsze podejście, produkcyjne, oparte było na zastosowaniu produkcji masowej w drugiej połowie XIX w. Spowodowane było to odkryciami geograficznymi i innowacjami technologiczno-organizacyjnymi, co umożliwiło zwiększenie efektywności produkcji i wydajności pracy, a także poszerzenie rynków zbytu $^{5}$.

Kolejna orientacja, sprzedażowa, której powstanie spowodowane było spadkiem zbytu w latach trzydziestych XX w. w związu z nastaniem wielkiego kryzysu, polegała na położeniu dużego nacisku na umiejętne zachęcanie klientów do zakupów. Producenci zaczęli zwracać uwagę na konieczność rozwoju kanałów dystrybucji, a także starali się zwiększać sprzedaż przez agresywne wyjście w rynek oraz zastosowanie narzędzi promocyjnych, takich jak reklama, rabaty itp. ${ }^{6} \mathrm{~W}$ efekcie jednak i taka orientacja napotkała bariery, m.in. zaleganie nadmiernej ilości produktów, które nie znalazły zainteresowania na rynku.

W połowie XX w. zaczęto więc stosować podejście marketingowe, którego podstawowym założeniem było to, że przed podjęciem decyzji co produkować, należało przeprowadzić badania rynkowe celem identyfikacji potrzeb nabywców ${ }^{7}$. Dynamiczny postęp technologiczny sprawił jednak, że potrzeby nabywców bardzo szybko zaczęły się zmieniać. Przeprowadzenie badań rynkowych przestało więc być gwarantem sukcesu dla podmiotów gospodarczych.

Od lat osiemdziesiątych XX w. orientacja zmieniła się na strategiczna. Ta z kolei wymagała umiejętności zidentyfikowania szans i zagrożeń przedsiębiorstwa w długim okresie. Jej celem była niejako możliwość szybkiej adaptacji podmiotów gospodarczych do zmieniających się obyczajów, nawyków, przepisów prawnych. Wymagało to od przedsiębiorstw tworzenia strategii ${ }^{8}$.

Z kolei orientacja społeczna, którą zauważono w ostatnich kilku latach, koncentruje się na określeniu potrzeb i pragnień, a także interesów odbiorców w taki sposób, aby móc zaspokajać ich oczekiwania skuteczniej, szybciej i bardziej wydajnie niż konkurencja, jednocześnie zachowując lub zwiększając dobrobyt klientów i społeczeństwa ${ }^{9}$.

Należy podkreślić, że zmiana orientacji przedsiębiorstw z produkcyjnej na społeczną jest przyczyną pośrednią digitalizacji sektora bankowego. Trudno jednak nie zauważyć związku między tymi dwoma aspektami. Wszystkie dostosowania przedsiębiorstw w każdym z sektorów wynikają bowiem z „kliento-,, i „społecznocentrycznej” orientacji marketingowej. Nie przykładając wagi do oczekiwań klientów, jakimi w dzisiejszych czasach są niewątpliwie wygoda

${ }^{5}$ R. Repetowski, Zmiany $w$ marketingowej orientacji przedsiębiorstw przemysłowych $w$ dobie postepujacej globalizacji, http://www.up.krakow.pl/geo/kgpptg/pdf/ptg12/reptowski12.pdf [dostęp: 4.07.2016].

${ }^{6}$ J. Radkowska, Marketing $w$ działalności przedsiębiorstw, w: eadem, K. Radkowski, D. Sobotkiewicz, Zarzadzanie marketingowe przedsiębiorstwem $w$ warunkach gospodarki rynkowej. Wybrane zagadnienia, PWSZ, Legnica 2009, s. 6-8.

${ }^{7}$ M. Sławińska, Istota $i$ znaczenie marketingu $w$ zarzadzaniu przedsiębiorstwem, w: H. Mruk, B. Pilarczyk, M. Sławińska, op cit., s. 20.

${ }^{8}$ K. Firlej, P. Trzepałka, Wybrane typy ogólnej orientacji przedsiębiorstw spożywczych XXI w., „Roczniki Naukowe Stowarzyszenia Ekonomistów Rolnictwa i Agrobiznesu” 17, 2015, z. 5, s. 53.

${ }_{9}^{9}$ P. Kotler et al., Marketing. Podręcznik europejski, PWE, Warszawa 2002, s. 19. 
korzystania z danego produktu czy usługi, szybkość ich dostarczenia lub łatwość użytkowania, przedsiębiorstwo nie miałoby prawa bytu.

Początkowo procesy związane z transformacją cyfrową traktowane były jak projekty adaptacyjne do zmian rynkowych i nikt nie rozpatrywał ich w kategoriach strategicznych dla banków ${ }^{10}$, nie spodziewano się bowiem, że rozwój nowych technologii będzie pozwalał na tak daleko idące zmiany w obsłudze klienta bankowego. Obecnie jednak ta sytuacja odwróciła się o 180 stopni. Działania digitalizacyjne banków przybrały bowiem taką formę, że trudno nie zauważyć w nich związków ze strategia, chociażby w ujęciu definicji 5P Mintzberga, który określa strategię jako plan, taktykę, model, pozycję oraz perspektywę ${ }^{11}$. Sama centralizacja i automatyzacja procesów wykorzystywanych w bankach, która jest głównym z elementów transformacji cyfrowej, mieści się w ramach definicji planu, modelu czy perspektywy. Tak więc zaznaczyć należy, że głównie z powodu rosnącej znacząco dynamiki postępu technologicznego digitalizacja ewoluowała z rangi projektu do strategii w sektorze bankowym.

\section{NOWE WYMAGANIA WOBEC BANKÓW}

Implementacja skutecznej transformacji cyfrowej sektora bankowego powinna być oparta na trzech głównych filarach, które stanowią jednocześnie nowe wyzwania dla banków ery digital:

- koncentracja na kliencie,

- otwartość na innowacje,

- elastyczność organizacyjna.

Koncentracja na kliencie w procesie digitalizacji polega, przede wszystkim, na skupieniu się na doświadczeniach klienta połączonych z dogłębnym zbadaniem aktualnej roli oddziałów banków: $3 / 4$ ankietowanych przez firmę doradczą AT Kearney respondentów odpowiedziało bowiem, że zrozumienie doświadczeń „bankowych” klientów jest kluczowe i niezbędne do przeprowadzenie efektywnego procesu transformacji ${ }^{12}$. Na tej podstawie wskazuje

10 Autor ma na myśli przypadki tradycyjnych banków, które prowadzą działalność od wielu lat, a transformacja cyfrowa jest w tych bankach wynikiem postępu technologicznego i zmiany przyzwyczajeń klientów, a nie odwrotnie. Działania te miały zatem charakter dostosowawczy. Wyjątki stanowią banki, które od początku swojej działalności przyjmowały strategię, że będą wykorzystywać nowoczesne technologie w prowadzeniu i rozwoju działalności bankowej. Można zatem powiedzieć, że w tych bankach nie zachodzi transformacja cyfrowa wg definicji zaprezentowanej przez autora, ponieważ żeby coś przechodziło transformację, musiałoby najpierw przyjmować inny kształt. Natomiast takie przykłady, jak T-Mobile Usługi Bankowe, dostarczane przez Alior Bank (dawniej Alior Sync), Nest Bank czy mBank pokazuja, że banki te od początku opierały swoją działalność w głównej mierze na dystrybucji produktów i usług oraz obsłudze klienta za pomocą kanałów zdalnych.

${ }_{11}$ H. Mintzberg, The Strategy Concept I: Five Ps for Strategy, http://www.milesazachary.com/ MGT\%204380\%20Sp\%202012/Mintzberg,\%20H.,\%201987.\%20The\%20Strategy\%20Concept\%20 I-Five\%20Ps\%20for\%20Strategy.pdf [dostęp: 17.12.2016].

12 AT Kearney, Going Digital: The Banking Transformation Road Map, https://www.atkearney.com/documents/10192/5264096/Going+Digital+-+The+Banking+Transformation+Road+M ap.pdf/60705e64-94bc-44e8-9417-652ab318b233 [dostęp: 6.07.2016]. 
się na trzy czynniki sukcesu realizacji wymogu „klientocentryczności”. Sa nimi uważność i pragmatyczność banku, gotowość i kreatywność oraz konieczność przeformułowania roli oddziałów. Ostatni czynnik oznacza w tym przypadku konieczność odejścia od tradycyjnej roli oddziału jako głównego kanału sprzedaży na rzecz miejsca, w którym klient zasięgnie wysokiej jakości porady od prawdziwego eksperta. Koncentracja na kliencie przyjmuje w bankach także formę tzw. Customer Experience Management (CXM), których celem jest wzrost satysfakcji klienta z relacji z bankiem. W ramach zarządzania doświadczeniami klienta banki zaczęły przykładać większą wagę do częstych kontaktów z klientem, żeby pokazać mu, jak jest istotny i jak bardzo zależy bankowi na jego zadowoleniu. Jednym z elementów CXM są nabierające wagi programy powitalne (OnBoarding), które mają na celu wzbudzenie pozytywnego nastawienia do banku od początku relacji.

Kolejne wyzwanie, przed jakim stoją banki ery cyfrowej, otwartość na innowacje, będzie się objawiała przez integrację marketingu i IT, co jest istota procesu digitalizacji. Innowacje sa geneza projektowania i dostarczania produktów i usług w epoce cyfrowej. Rynek zmienia się szybko, więc bycie na fali wymaga wysoce efektywnego połączenie pomiędzy nowymi technologiami a jednostkami biznesowymi banku.

Kluczowa w procesie cyfryzacji będzie także „zwinność” technologiczno-organizacyjna. Elastyczne platformy IT mają bowiem zasadnicze znaczenie dla digitalizacji modeli operacyjnych banków. Możliwości technologiczne stają się bowiem głównym wyróżnikiem dla banków, jeśli chodzi o poprawę satysfakcji klientów.

Realizacja trzech wyżej opisanych wymagań jest warunkiem spełnienia oczekiwań klienta ery cyfrowej. Wśród takich oczekiwań należy wyróżnić:

- zindywidualizowaną ofertę, przy jednoczesnym braku tolerancji na propozycje nietrafione (czyli masowo rozsyłane oferty, o jednakowych warunkach dla wszystkich adresatów);

- mobilność i ciagła dostępność banku dla klienta;

- połączenie usług bankowych z szeroką gamą usług innych dostawców (możliwość zamawiania taksówek, zakup biletów do kina, płatność z użyciem kodów QR, możliwość podziału opłacanego rachunku między znajomymi i inne);

- łączenie funkcjonalności karty płatniczej z innymi kartami, np. karta paliwowa, lojalnościowa, zdrowotną itp.;

- dostęp online do wszystkich produktów bankowych, w tym do pełnej obsługi kredytu, począwszy od złożenia wniosku do wypłaty środków bez konieczności wizyty w oddziale;

- możliwość pozyskania opinii znajomych na temat danego produktu czy usługi;

- realizacja usługi natychmiast po zgłoszeniu zapotrzebowania;

- wygoda i łatwość obsługi ${ }^{13}$.

${ }^{13}$ A. Pyka, A. Sieradz, Bank detaliczny ery „Digital”, w: A. Kawiński, A. Sieradz, Wyzwania informatyki bankowej, EKF, Gdańsk 2015, s. 21-22, 24. 
Warto również wyjaśnić, skąd się wzięły te nowe wymagania wobec banków oraz jak powstał klient ery digital. Otóż wszystko stało się za sprawą Internetu i jego rozpowszechniania w niemalże wszystkich sferach życia człowieka. W Polsce pierwsze wirtualne połączenie ze światem nastapiło 17 sierpnia 1991 r. pomiędzy Wydziałem Fizyki Uniwersytetu Warszawskiego a Centrum Komputerowym Uniwersytetu w Kopenhadze, co uważa się za symboliczna datę wprowadzenia Internetu. Faktycznie jednak był to 15 grudnia 1991 r., kiedy Stany Zjednoczone zniosły dla naszego kraju embargo na dostęp do nowoczesnych technologii komputerowych i telekomunikacyjnych ${ }^{14}$. Od tamtej pory Polska szybko zaczęła gonić cyfrowy świat, włączając się w nurt społeczności internetowej. Dla sektora bankowego przełomem był jednak rok 2007, kiedy na rynek wypuszczony został pierwszy model iPhon'e, czyli smartfona dającego mobilny dostęp do Internetu. Jak dynamiczny stał się rozwój rynku smartfonów, prezentuje wykres 1 .

Wykres 1

Roczna sprzedaż smartfonów w latach 2008-2020 (w mln szt.)

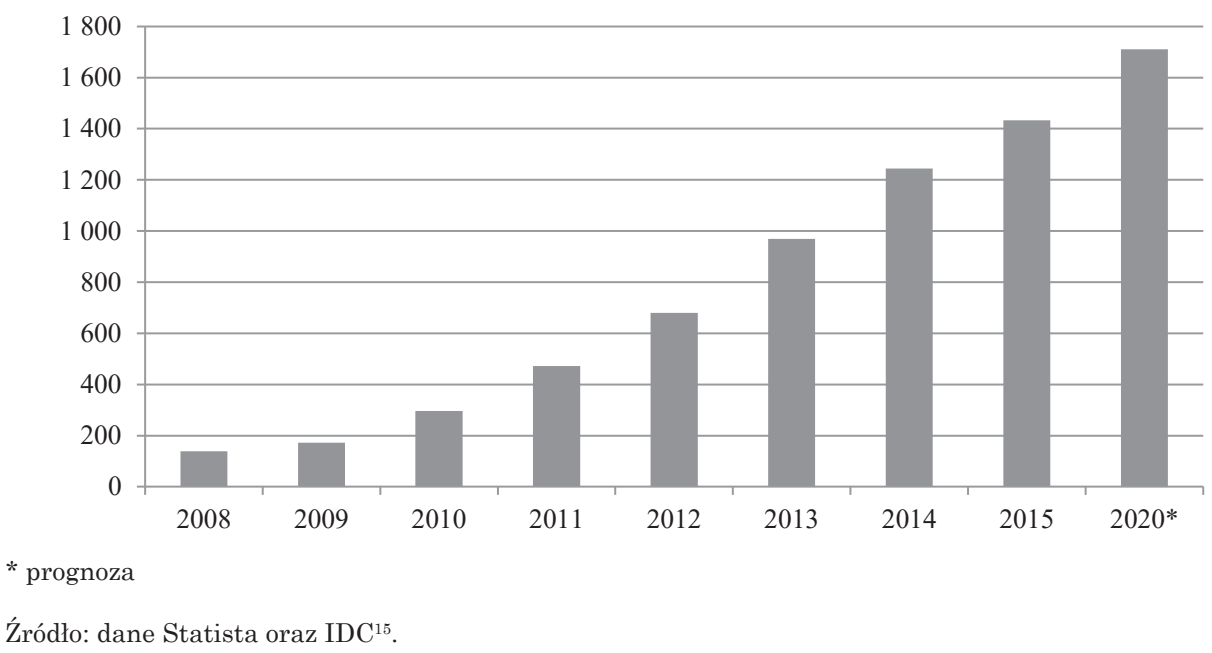

Zgodnie $\mathrm{z}$ danymi przedstawionymi na wykresie w ciagu zaledwie siedmiu lat sprzedaż smartfonów wzrosła ponad dziewięciokrotnie, a prognoza na $2020 \mathrm{r}$. wskazuje, że względem 2008 r. wzrost ten będzie ponad dwunastokrotny.

Banki, obserwując taką dynamikę wzrostu rynku smartfonów, dostrzegły możliwość wprowadzenia nowoczesnych rozwiązań do swojej działalności.

${ }^{14}$ D. Baran, Internet $w$ Polsce, https://repozytorium.ka.edu.pl/bitstream/handle/11315/667/ DBaran_Internet\%20w\%20Polsce.pdf?sequence=1 [dostęp: 4.07.2016].

15 Zob. https://www.statista.com/statistics/263437/global-smartphone-sales-to-end-users-since-2007/, https://www.idc.com/getdoc.jsp?containerId=US42060116 [dostęp: 6.07.2016]. 
W ten sposób powstała tzw. bankowość mobilna, czyli dostęp do usług bankowych za pomoca aplikacji zainstalowanej w smartfonie. Bankowość mobilna stała się nawet bardziej popularna niż bankowość internetowa, która z kolei zaczęła być traktowana jako standard rynkowy, co pokazuje, jak duży odsetek społeczeństwa niezależnie od grupy wiekowej posługuje się tym rozwiązaniem.

Popularność i koncentracja na rozwiązaniach mobilnych wynikaja zatem z dużego zainteresowania tymi możliwościami wśród najmłodszych klientów banków, czyli tych, którzy tworzą pokolenie digital. To z myślą o nich banki dziśs zmieniają swoje strategie. Rozkład aktywności klientów ze względu na wiek prezentuje wykres 2 .

Wykres 2

Użytkownicy bankowości mobilnej i internetowej

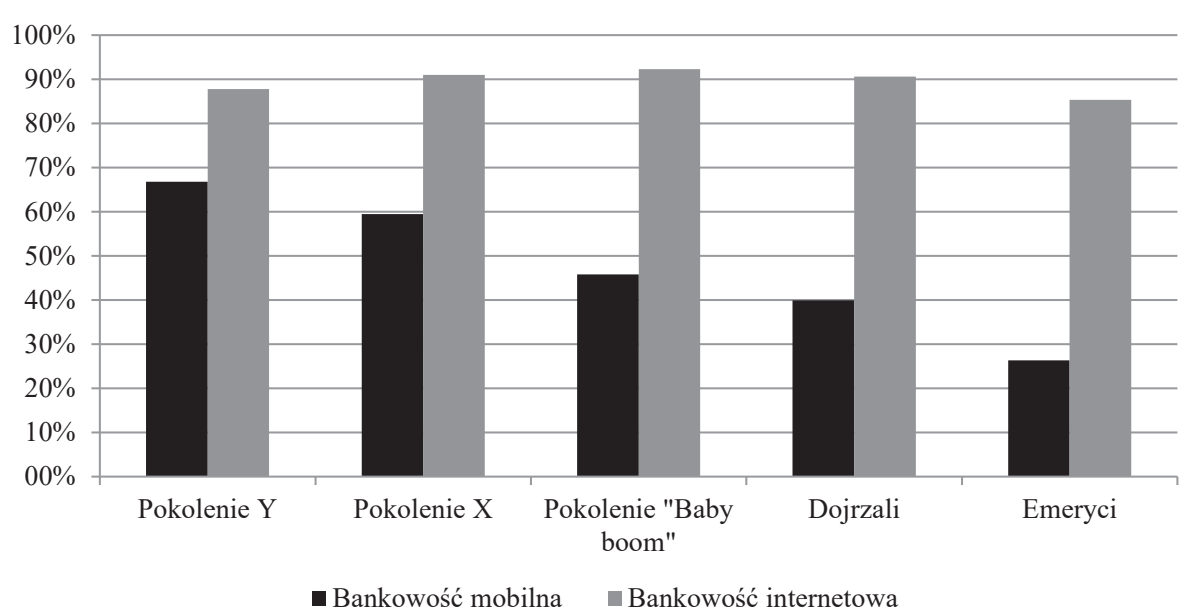

Źródło: dane $\mathrm{PwC}^{16}$.

Jak wskazuje wykres, amplituda odsetka użytkowników bankowości internetowej wynosi zaledwie 6,9 p.p., natomiast w przypadku bankowości mobilnej ta różnica wynosi aż 40,5 p.p., co ewidentnie wskazuje, że mobilne rozwiązania są raczej domeną pokoleń zdigitalizowanych. Jest to m.in. wynikiem bariery spowodowanej zmniejszonym przyjmowaniem się nowoczesnych rozwiązań technologicznych wśród ludzi starszych.

Naturalną konsekwencją rozwoju bankowości mobilnej stały się płatności mobilne, oparte na założeniu, że dokonywanie smartfonem płatności także ma duży potencjał biznesowy. O dużym potencjale świadczy chociażby fakt,

${ }_{16} \mathrm{PwC}$, The new digital tipping point, https://www.pwc.com/gx/en/banking-capital-markets/ publications/assets/pdf/pwc-new-digital-tipping-point.pdf [dostęp: 16.12.2016]. 
że do gry o udział w rynku płatności mobilnych poza bankami i organizacjami kartowymi, takimi jak Visa czy MasterCard, stanęły także inne firmy spoza branży finansowej, np. sieci komórkowe, producenci smartfonów, duże sieci detaliczne oraz dostawcy usług internetowych ${ }^{17}$. Od wielu lat na rynku płatności mobilnych dominują technologie zbliżeniowe NFC (Near Field Communication), czyli bezprzewodowe technologie krótkiego zasięgu, które pozwalaja aplikacjom mobilnym aktywnie współpracować z biernymi urzadzeniami fizycznymi (np. terminalami), przekazując im niezbędne dane do wykonania transakcji. Dane karty sa w takich płatnościach przechowywane na karcie SIM lub „naklejce zbliżeniowej” przyklejonej do telefonu ${ }^{18}$. W zupełnym świecie digital cenniejsze stają się jednak technologie HCE (Host Card Emulation), które banki powoli zaczynaja oferować swoim klientom, nie jest to jednak jeszcze standardem. Technologia HCE jest znacznie bezpieczniejsza dla użytkownika płatności zbliżeniowych, ponieważ pozwala na przechowywanie danych karty bezpośrednio w banku, nie jest więc wymagane łączenie $\mathrm{z}$ operatorem.

\section{KORZYŚCI PRZEPROWADZENIA TRANSFORMACJI CYFROWEJ W BANKACH}

Poza zmieniającymi się zachowaniami klientów, które wymuszają szybkie reagowanie ze strony banków, uwagę należy także zwrócić na korzyści, jakie dostrzegają pierwsze podmioty realizujące strategię. Analiza McKinsey\&Company ${ }^{8}$ wskazuje, że przychody i zyski będą migrować w kierunku banków, które z powodzeniem korzystaja $\mathrm{z}$ technologii cyfrowych $\mathrm{w}$ celu automatyzacji procesów, tworzenie nowych produktów, polepszania zgodność z przepisami czy poprawy doświadczeń swoich klientów. Instytucje, które są odporne na innowacje cyfrowe, będą karane przez klientów, rynki finansowe, a czasami nawet regulatorów. Możliwe zmiany w zysku banków prezentuje schemat 1 .

Wyżej przedstawiona analiza nie pozostawia wątpliwości, że cyfryzacja ma przed sobą przyszłość - zarówno z punktu widzenia klienta, jak i samego banku oraz jego korzyści. Banki, które nie przeprowadzą w najbliższym czasie transformacji cyfrowej, skazane są na porażkę na konkurencyjnym rynku. Jedynym wyjściem dla takich banków będzie wystawienie się na sprzedaż. Potwierdzeniem istotnego udziału klientów cyfrowych w wynikach banków jest również kolejna analiza, której wynik przedstawiony został na wykresie 3.

${ }^{17}$ B. Nocoń, B. Zborowski, Bankowość mobilna i płatności mobilne, w: A. Kawiński, A. Sieradz, op. cit., s. 13.

18 A. Cavoukian, Mobile Near Field Communications (NFC). "Tap 'n Go". Keep it Secure \& Private, https://www.ipc.on.ca/images/Resources/mobile-nfc.pdf [dostęp: 4.07.2016]. 


\section{Schemat 1}

Wpływ transformacji cyfrowej na zmiany zysku banku detalicznego

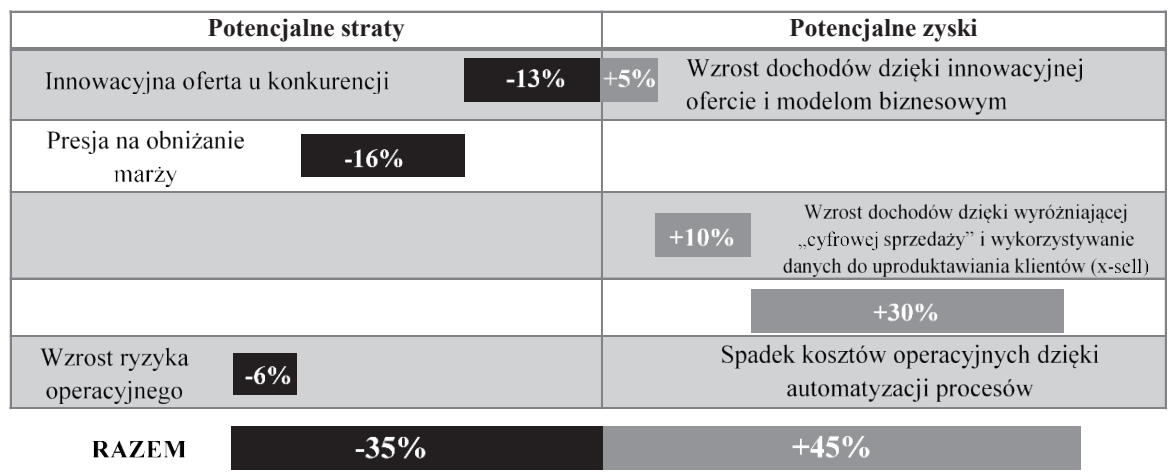

Źródło: analiza McKinsey\&Company ${ }^{19}$.

\section{Wykres 3}

Przychody z bankowości detalicznej w Polsce (w mld zł)

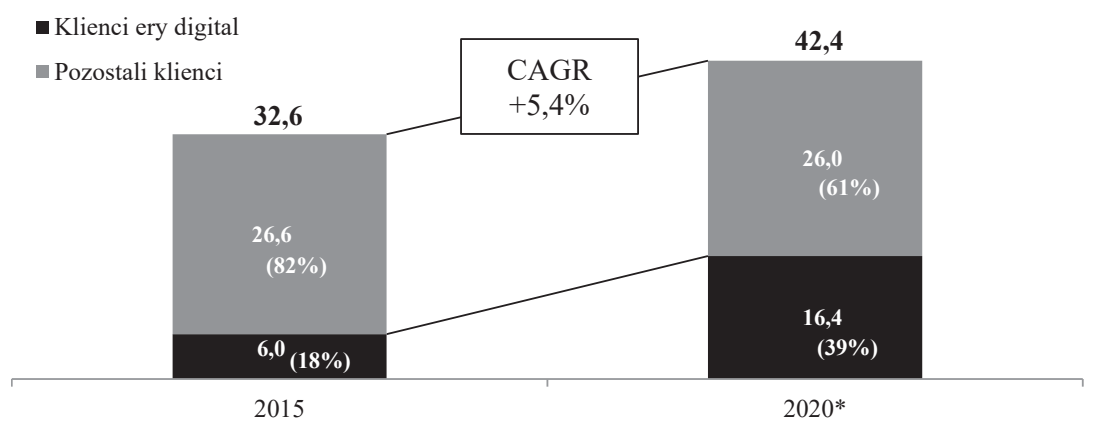

Źródło: szacunki Deloitte, Gernalto, The Millennial Disruption Index ${ }^{20}$.

Zgodnie z informacjami zaprezentowanymi na wykresie udział poszczególnych grup klientów w przychodach banków detalicznych drastycznie się zmieni. Prognozowany jest ciagły przyrost przychodów generowanych w kanałach mobilnych przez klientów cyfrowych. Udział pozostałych będzie się szybko zmniejszał, nie tylko przez szybszą dynamikę wzrostu klientów zdigitalizowanych, ale i przez utrudniony dostęp do tradycyjnych produktów bankowych

19 McKinsey\&Company, Strategic choices for banks in the digital age, http://www.mckinsey.com/industries/financial-services/our-insights/strategic-choices-for-banks-in-the-digital-age [dostęp: 8.07.2016].

${ }^{20}$ Deloitte, Wizja banku przyszłości $w$ rzeczywistości digital, Warsztat z Deloitte z 27 kwietnia 2016 r. (materiał nieopublikowany). 
spowodowany stopniowym zmniejszaniem się liczby placówek stacjonarnych. Transformacja cyfrowa zapewni bankom stabilny, skumulowany roczny wskaźnik wzrostu na poziomie $5,4 \%$.

\section{STAN OBECNY I ZADANIA NA NAJBLIŻSZE LATA}

$\mathrm{Z}$ badań $\mathrm{PwC}^{21}$ wynika, że wśród zarządzających bankami znacząco rośnie świadomość potrzeby zmian, mimo to występuje duża luka w gotowości: $61 \%$ menedżerów odpowiedziało, że model biznesowy zorientowany na klienta jest bardzo ważny, a 75\% banków ponosi w tym obszarze znaczne nakłady na inwestycje. Jednak tylko 17\% czuje się dobrze przygotowana. Niżej przedstawione zostały obszary wymagajace znacznego wysiłku według zarządzających bankami.

\section{Wykres 4}

Obszary wymagające uwagi w ciągu najbliższych pięciu lat według menedżerów w bankach na świecie

Ulepszenie systemów gromadzenia danych o kliencie

Ocena danych dot. skuteczności i dobrych praktyk z punktu widzenia klienta

Dopuszczenie do zwiększonego udziału klienta w określaniu cech produktu, w tym cen

Używanie portali społecznościowych do monitorowania preferencji klienta

Przeprowadzanie segmentacji klientów za pomocą dedykowanej grupy, która wspiera rozwój całej strategii

Oferowanie klientom różnych kanałów obsługi, zarówno samodzielnych, jak i umożliwiających interakcję osobistą

Stworzenie elastycznego portfela produktów dostosowanego do segmentu klienta

Stworzenie stanowiska w randze członka zarządu nadzorującego nowy model biznesowy

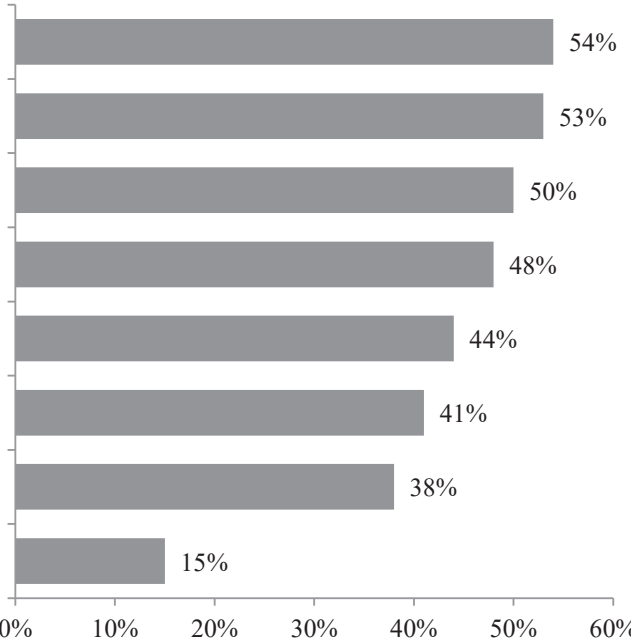

Źródło: $\mathrm{PwC}^{21}$.

Najwięcej zarządzających bankami wskazało konieczność ulepszenia systemów gromadzenia i integracji danych o kliencie. Dane są dużym wyzwaniem dla banków, a poleganie na przestarzałych metodach ich zbierania, przechowywania i wykorzystywania stanowi realne zagrożenie dla modeli działalności

${ }^{21} \mathrm{PwC}$, Retail Banking 2020. Evolution or Revolution?, https://www.pwc.com/gx/en/banking-capital-markets/banking-2020/assets/pwc-retail-banking-2020-evolution-or-revolution.pdf [dostęp: 8.07.2016]. 
bankowej. Wraz z pojawianiem się nowych usług bankowych i kanałów dystrybucji, banki nieustannie rozwijają nowe techniki zapobiegania oszustwom i zapewnienia ochrony klientów. Jednym z niewielu obszarów, w którym przestarzałe metody zbierania i przetwarzania danych wciąz są intensywnie wykorzystywane, jest identyfikacja tożsamości klienta. Przeprowadza się ją zazwyczaj na podstawie dowodu osobistego lub prawa jazdy, które klient musi okazywać w wielu interakcjach z bankiem. Brak możliwości wymieniania się danymi klientów przez poszczególne kanały dystrybucji zawodzi oczekiwania klientów ery digital, którzy życzyliby sobie błyskawicznej obsługi i jak najmniej kłopotliwych procedur. Wobec zwielokrotnionych punktów zaangażowania w relacje z bankiem, w różnych grupach usług - takich jak kredyty konsumpcyjne i hipoteczne czy karty kredytowe - nie można żądać od klientów, aby powtarzali i ponownie wprowadzali swoje dane przy zamiarze skorzystania z kolejnej usługi oferowanej im przez bank. Dane te powinny już znajdować się w posiadaniu banku, a możliwość łatwego współkorzystania z nich przez poszczególne piony powinna być standardem. Dobrym rozwiązaniem w tym zakresie jest biometria, którą część banków zaczęła już stosować ${ }^{22}$. Pozwala ona na przeprowadzenie identyfikacji klienta za pomoca odcisków palca lub głosu. Jest to doskonałe narzędzie dla kochających nowości technologiczne.

Najmniej menedżerów wskazało na konieczność powołania członka zarządu banku nadzorującego nowy model biznesowy. Ma to swoje odzwierciedlenie w polskich realiach, ponieważ dotychczas tylko jeden bank oficjalnie prezentuje na stronie internetowej członka zarządu pełniącego funkcję Chief Digital Officer - jest to Bank Zachodni WBK.

\section{DOTYCHCZASOWE OSIĄGNIĘCIA POLSKIEGO RYNKU W ZAKRESIE DIGITALIZACJI PRODUKTÓW I USEUG BANKOWYCH - WYBRANE PRZYKŁADY}

Autor identyfikuje trzy obszary, w ramach których banki wprowadzaja rozwiązania cyfrowe - produkty, obsługa klienta oraz usługi pozabankowe. Głównym elementem, na jakim banki skupiły się w ramach obszaru prod u k tow e go, było udostępnienie możliwości otwierania konta przez Internet, ponieważ jest to najczęściej kupowany produkt bankowy, stanowiący niejako podstawowa potrzebę kontaktu klienta $\mathrm{z}$ bankiem. Co istotne, autoryzacja i weryfikacja tożsamości klienta może przebiegać w dwojaki sposób - przez dokonanie przelewu identyfikującego z konta w innym banku (proces w pełni zdalny) lub przez sprawdzenie dokumentu tożsamości przez kuriera, w obecności którego podpisywana jest umowa przygotowana na podstawie wniosku złożonego za pośrednictwem internetowego formularza (proces częściowo zdalny). Chciałoby się powiedzieć, że założenie konta przez Internet jest dziś ogólnodostępną usługą. Banki napotkały jednak w tym zakresie pewne utrudnie-

\footnotetext{
22 Przykłady banków wykorzystujących biometrię przedstawione są w pkt VI.
} 
nia wraz z wejściem w życie od 1 lipca 2016 r. rekomendacji Komisji Nadzoru Finansowego dotyczacej bezpieczeństwa transakcji płatniczych wykonywanych w Internecie przez banki, krajowe instytucje płatnicze, krajowe instytucje pieniądza elektronicznego i spółdzielcze kasy oszczędnościowo-kredytowe. W myśl rekomendacji bank może oferować otwieranie konta przez Internet z weryfikacją tożsamości przez przelew z innego konta wyłącznie wtedy, kiedy jest w stanie uniemożliwić wykorzystanie otwartego w ten sposób konta, do potwierdzenia tożsamości przy otwieraniu kolejnego rachunku w innym banku. Ograniczyło to w znacznym stopniu w pełni zdalną sprzedaż kont, ponieważ banki muszą dostosować architekturę IT to tego wymogu. Przykładowo Bank Zachodni WBK uniemożliwił zupełnie otwieranie konta w ten sposób, gdyż jego systemy nie pozwalają na blokowanie używania „kont na przelew” do otwierania kolejnych kont tego typu.

Sytuacja z pozostałymi produktami jest jeszcze trudniejsza, co potwierdza dostępność ich zakupu w kanałach zdalnych. Spośród największych banków w Polsce ${ }^{23}$ kredyt gotówkowy przez Internet można kupić wyłącznie w ING Banku Ślaskim, Millenium Banku i mBanku, przy czym warto podkreślić, że - jak już wcześniej wspomniano - strategia mBanku od początku jego działalności była nakierowana na zdalną dystrybucję i obsługę produktów. Pozostałe banki nie posiadają formularzy online, oferują jednak możliwość procesowania wniosku o udzielenie kredytu za pośrednictwem infolinii. Takie rozwiąanie nie jest jednak w pełni cyfrowe, ponieważ finalizacja musi nastapić w placówkach bankowych. Znacznie lepiej wygląda możliwość zakupu kredytu online przez dotychczasowych klientów banku. Posiadanie przez użytkownika usług bankowości elektronicznej (internetowych lub mobilnych), nie wymaga jego weryfikacji przy podpisywaniu umowy. Zatem wszystkie analizowane banki dają możliwość zaciagnięcia kredytu za pośrednictwem usług e-bankowych klientom wewnętrznym. Podobnie jest z otwarciem dodatkowego konta, przy czym klienci wewnętrzni znacznie częściej zaciągają w swoim banku kredyt, niż otwierają kolejne konto.

Jeśli chodzi o kolejny obszar, jakim jest obsługa klienta, największy postęp technologiczny odnotowano w zakresie identyfikacji klientów. Innowacyjnym rozwiązaniem w tym zakresie jest przywołana w punkcie V biometria. Pionierem w tym zakresie jest Bank Polskiej Spółdzielczości, który jako pierwszy w Europie wprowadził w 2010 r. bankomat ze skanerem układu naczyń krwionośnych palca. Zastosowano w nim technologię Finger Vein, opracowaną przez japońską firmę Hitachi. Innym przykładem wykorzystania biometrii jest Bank BPH, który począwszy od 2013 r., na dużą skalę zastosował unikalny wzorzec naczyń krwionośnych wewnątrz palca zamiast dowodu osobistego do identyfikacji klienta w oddziałach. Kolejnym bankiem, który poza innowacyjnością wyróżnia się także opisaną w punkcie III „zwinnością organizacyjną, jest Getin Bank. Krótka ścieżka decyzyjna pozwoliła uruchomić pierwszy oddział Getin Banku z czynnikami biometrycznymi w ciagu zaledwie czterech

${ }^{23}$ Autor przeanalizował ofertę następujących banków: Pekao S.A., PKO BP S.A., BZ WBK S.A., ING BŚ S.A., Millenium Bank S.A., mBank, Alior Bank oraz Getin Bank. 
miesięcy od momentu podpisania umowy wdrożeniowej z firmą realizujacca projekt. Szybkość i elastyczność powoduja, że jest to obecnie najnowocześniejszy bank w Polsce ${ }^{24}$. Inny rodzaj biometrii zastosował z kolei Bank Zachodni WBK - do identyfikacji klientów korzystających z usług banku za pośrednictwem infolinii wykorzystuje od 2016 r. próbki głosu.

Ostatnim z obszarów podlegających digitalizacji są usługi pozabankowe, z których coraz częściej można korzystać za pośrednictwem platform bankowych. Doskonałym przykładem w tym zakresie jest bardzo szybkie wdrożenie przez banki projektów technologicznych umożliwiających ich klientom składanie wniosków o zasiłki na dzieci z programu „Rodzina 500+”. Funkcjonalność tę udostępniły wszystkie analizowane przez autora banki (zob. przyp. 12). PKO Bank Polski oferuje także bezpłatnie możliwość załatwiania innych spraw administracyjnych za pomoca usług bankowości elektronicznej. Przez platformę iPKO można komunikować się m.in. z Zakładem Ubezpieczeń Społecznych oraz Centralną Ewidencją i Informacja o Działalności Gospodarczej. Zupełnie odchodzacym od klasycznych usług bankowych przykładem są możliwości, jakie daje aplikacja mobilna Banku Zachodniego WBK. Za pośrednictwem tego narzędzia można zamówić kwiaty lub taksówkę, opłacić parking oraz kupić bilety komunikacji miejskiej. Przykłady te pokazuja, jak duże możliwości w konkurowaniu o uwage nowoczesnego pokolenia mają banki. Stracą te z nich, które tych możliwości nie dostrzega.

\section{PODSUMOWANIE}

Uświadomienie sobie konieczności zmiany strategii i aktualnego modelu biznesowego banku jest pierwszym, a zarazem najważniejszym wyzwaniem, jakiemu prezesi banków muszą sprostać. Zakres zmian obejmujacych transformację cyfrowa pokazuje, że digitalizacja jest trudnym i skomplikowanym przedsięwzięciem. Wykorzystanie szans i możliwości, jakie niesie transformacja, będzie wymagać od banków inwestycji, żmudnego planowania i skoordynowanego procesu podejmowania decyzji obejmujących cały bank. Ale wysiłek się z pewnością opłaci, w przeciwnym razie konkurenci wyręczą banki, dostarczając oczekiwane rozwiązania klientom nowej ery.

mgr Piotr Druszcz

Uniwersytet Ekonomiczny w Poznaniu

piotr.druszcz@ue.poznan.pl

${ }^{24}$ T. Woszczyński, Z. Marcinkowski, M. Sudoł, Raport biometryczny 2.0. Bankowość biometryczna, http://zbp.pl/public/repozytorium/dla_bankow/rady_i_komitety/technologie_bankowe/ publikacje/Raport_Biometryczny_2.0_strona_FTB.pdf [dostęp: 18.12.2016]. 


\section{DIGITISATION OF BANKING PRODUCTS AS A STRATEGIC OBJECTIVE FOR THE BANKING SECTOR PARTICIPANTS}

\section{Sum mary}

The article tackles one of the main current objectives of the banking sector nowadays, which is digital transformation of banks' activity, both internal and external. The evolution of society resulting from the introduction of the Internet to almost all areas of human life forces banks to automate and digitise all the processes and banking products in order to meet the demands of the modern customer. Therefore, banks have to reformulate their current strategies and focus on clients and their preferences, who should become the centre of attention. The article considers the challenges which the Polish banking sector is facing and identifies the possible consequences of the failure to adjust the banks to customer expectations. 